\title{
Religious Tolerance According to the Forum for Religious Harmony (FKUB), Central Java
}

\author{
Mudjahirin Thohir \\ \{mudjahirinthohir@ymail.com\} \\ Department of Anthropology, Faculty of Humanities, Diponegoro University \\ Jl. Prof. Soedarto, S.H. Undip Tembalang, Semarang, Central Java - Indonesia, 50275
}

\begin{abstract}
Religion in social life, presents peace, while presenting the potential for social segregation. This is a logical consequence of various religions as well as diverse religious communities. Many causes, but this study focuses on the issue of religious tolerance. What do you think of the religious leaders, the administrators of the Religious Harmony Forum (FKUB) in Central Java? The results show that (1) intolerant attitudes and actions still arise among followers of the religion itself; but (2) efforts to be tolerant have been made. The FKUB's task in the field is (3) to change the religious perspective, from a theological and sociological perspective in a balanced manner. (4) FKUB conducts ongoing socialization in the form of dialogues, discussions, seminars, and preparation of books. (5) Efforts to do so are often constrained by low funding from the local government.
\end{abstract}

Keywords: religion, tolerance, perspective, dialogue.

\section{Introduction}

Until now, the intolerance of religious groups is still common. This condition indicates that in the life of a pluralistic society, religion for followers, can present two sides: conflict or harmony. It is reasonable that the Forum for Religious Harmony (FKUB) is campaigning for a tolerant attitude between religious communities.

Based on this phenomenon, this study will examine the views of the Central Java FKUB administrators about what tolerant religious life is like. How are the conditions to foster a tolerant attitude in a pluralistic life in the Central Java region? What has been done by the FKUB administrators in each region (district / city) in Central Java?

To understand the issue, the data was extracted in the form of discussions, seminars, and regional coordination meeting documents (Rakorda FKUB). Discussions and seminars are conducted repeatedly in different places: Solo Raya, Semarang, and Pekalongan.

Henceforth, the data is analyzed qualitatively to find religious views, religious maturity, and religious actions. Such studies are used to mark the characteristics of religious maturity in a pluralistic society.

\section{Discussion}

\subsection{Issues of Religious Views}


To assume that all religions are true, or that only the religion that is embraced is true, is equally untrue. Why? Because the first is to position religion secularly even though religion is sacred. Whereas the second is seeing with the ethnocentric self-religion.

In other words, the religion is really true, aimed at its adherents, not for the followers outside. This means, if we say that "the religion we choose is true", then at the same time I have to give "them" space to say "truth" to the religion that is adopted. This is the understanding to base life together in differences. Therefore, the key word for interfaith believers to live side by side peacefully is if they are able to respect the degree in disagreement.

To be mature in religion, it is not easy. Why? because "so far", the process of religious socialization carried out by religious leaders, often ignored the importance of coexistence with various adherents of different religions. Especially if the public media does not care to reduce it.

How is it ideal? First, understand that 'the religion that we embrace is true in our opinion, so they also have the same right to declare the truth according to them'. Second, if they 'disturb' our religion, they are actually tarnishing their own religious glory. Similarly, if we disturb their beliefs, in fact we also tarnish our own religion.

Here there is a moral message, namely religious belief is the right of the individual to deal with God. Being looking at those who are of different religions as brothers is part of our expression of conscience as civilized human beings. So, our job is to make Indonesia a big building, where each person can feel comfortable living in it.

Such expectations are a challenge for religious people, including religious leaders. The question is, what about religious conflicts precisely because of the views and attitudes of the religious leaders themselves? This is the duty of the FKUB to design religious life in harmony with plural societies such as Indonesian society.

\subsection{Variety of religious life of the community and its excesses}

If religious life in a plural society occurs in harmony, or causes symptoms of intolerance, then it can happen for several reasons.

Data from a number of discussions, seminars, and coordination meetings (rakorda) of the FKUB, they believe that intolerance can be caused by several reasons: (a) In each religion, there are indeed teachings that give the adherents an opportunity to be alert, suspect, and even negatively judge religion and followers of other religions; (b) Attitudes suspect that they can come from adherents, not from religious teachings. This happens for several reasons. There is suspicion for followers of other religions behind building a place of worship. Places of worship are seen as a means, for example: Islamization or Christianization. Though the choice of religion according to their respective adherents, is related to the fate in the hereafter later: placed in heaven or hell; (c) religious conflicts are deliberately created by outsiders, by politicizing the teachings of religion itself. In other words, incoherence often arises when there is politicization of religion.

\subsection{The stages of dialogue are differences}

How to find the beauty behind religious differences? One of them is by dialogue. To traditionalize dialogue in order to realize harmony, both internally and among people, can be expressed in three stages of dialogue, namely (1) daily dialogue; (2) dialogue as a social obligation of religious followers; and (2) faith dialogue.

Daily dialogue can be done both personally and communally, in spontaneous, nonformal, or in planned dialogues that are communal. 
This is on local wisdom that "if you don't know, you don't dear". It is from "knowing" that we can begin to share our understanding of ourselves and others, while reducing our suspicion and hatred.

An dialogue as a social obligation of religious followers describing ourselves as believers is obliged to improve life together. Mutual cooperation to cope with disasters, for example, is an important moment as a believer and as a citizen to help. In mutual cooperation, we do not discriminate against the religion that is embraced. From mutual cooperation, it will present a positive view as a characteristic of religious people.

If the first and second dialogs have gone well, then dialogue on faith matters can begin. The dialogue of faith is not to justify which religion is true and which religion is wrong, but precisely how to learn to understand and find positive values behind differences in religion and religious teachings.

From the dialogue of faith, born the attitude: "to respect to the others, only be presented after we understand them". From this point of view, FKUB believes that differences are beautiful, and the duty of religious people is to find the beauty behind differences itself.

\subsection{The principle of being Indonesian}

To say that "I am a citizen of Indonesia, adherents of a religion (Islam or Protestant or Catholic or Buddhist or Hindu or Confucian)", it seems more showing nationalism as a very strong Indonesian citizen. Such an attitude is positive for prioritizing the integrity of Indonesia. That way, means as a sign of being able to cooperate with people of different religions. This is different if you say "I am a follower of religion (Islam or Protestant or Catholic or Buddhist or Hindu or Confucian) who lives on Indonesian soil (because it happens to be a resident of Indonesia)".

In general, FKUB members, as workshop participants, prefer the first statement. If there are still many Indonesians out there choosing the second statement, it means that there is still homework to be done to build tolerance. Homework to build such tolerance, is certainly not easy, not as easy as turning your hand.

\section{Conclusion}

We must dare to be honest that "religious" conflicts, similar to diseases, can never be completely eliminated. What can be done is reduce it. Reducing the potential for religious conflict by developing "cultural" tolerance as a measure of maturity in religion. Why? Because, the tolerance is one of the characteristics of religious maturity itself. For this reason, teaching religion to followers (adherents), it is not enough to just introduce religious teachings without teaching how to live religiously in the context of a pluralistic society

The ability for religious leaders to teach tolerance, requires that they know the meaning behind religious texts (if in Islam: the Qur'an and al hadith), and know the meaning of their social texts and context. Religious texts are not subject to or subjugated by modernity (as a representation of the dynamics of social texts including submission to the advancement of modern science and modernization) but the religious texts are condemned. Such religious reasoning (reading: understanding) is important. From this point the function of religion became a source of superior civilization. Not the other way around, positioning religion as an artifact item that is only needed by archaeologists or philologists for the object of study.

So, understanding religion to its followers is positioning religion as a "compilation of civilizations". For this reason, humans can find that in religion, there are found the peaks of 
civilization: high work ethics, honesty, discipline and achievement because they bear the title that humans are "kholifah fil ardli".

For this reason, the issue of religion should not be limited to the realm of mysticism, not to entertain the losers, and not as an endorser of violence for angry people. Religion is a means to be able to live together tolerantly.

\section{References}

[1] Abegebriel, A Maftuh, A. Yani Abeveiro, dan SR-Ins Team: Negara Tuhan - The Thematic Encyclopedia. Jakarta: SR-Inc Publishing. (2004)

[2] Buchori, Moctar: "Radikalisme Agama - Sebuah Catatan Awal", dalam Pesantren, No. 4/Vol.III. Hlm. 55-69. (1986)

[3] Burrel, RM, ed: Fundamentalisme Islam. Yogyakarta: Pustaka Pelajar Ofsett. (1995)

[4] Effendy, Bahtiar dan Sirry, Mun'in A: "Ekstremisme Islam: Bukan Sekadar Persoalan Teologis atau Penafsiran Keagamaan", dalam Jurnal Demokrasi \& Ham. Vol. 3, No. 1, Januari - April. Hlm 105121. (2003)

[5] Kuntowijoyo: "Dari Kerukunan ke Kerjasama, dari Toleransi ke Kooperasi”. Majalah Ummat, no.14, th I, 8 Januari (1996)

[6] Lubis, M Ridwan: "Kerukunan Umat Beragama sebagai Kebutuhan dalam Pandangan Agama". Makalah Konferensi Nasional FKUB, 21 sd 23 Mei 2017 di Medan Sumatra Utara (2017).

[7] Priyono, A: "Fenomena 'Terorisme Agama' dan Kebangkitan Neo-Fundalisme Islam di Indonesia Pasca Orde Baru", dalam Jurnal Demokrasi \& Ham. Vol. 3, No. 1, Januari - April. Hlm: 6 -34. (2003)

[8] Rofiq, Aunur: Tafsir Resolusi Konflik. Malang: Uin-Maliki Press. (2012)

[9] Suradji, Adjie: "Serigala di Kandang Domba”, Kompas, 28 Juli 2017, Hlm: 7.(2017)

[10] Thohir, Mudjahirin: Multikulturalisme. Agama, Budaya, dan Sastra. Semarang: Gigih Pustaka Mandiri (2013)

[11] Thohir, Mudjahirin (dkk. Eds): Menyemai Kedewasaan Beragama di Indonesia. Demak: Sinar Ilmu Jaya. (2015) 